\title{
ELECTROSTIMULATION OF THE MEDIAN NERVE IN TETRAPLEGICS BY MEANS OF IMPLANTED STIMULATORS
}

\author{
By Professor Jerzy Kiwerski, the late Professor Marian Weiss and \\ ROMAN PAŚNICZEK.
}

The Institute of Rehabilitation, Warsaw School of Medicine, Konstancin, Poland.

Summary. The effect of direct electrostimulation of the median nerve in a group of tetraplegic patients is described. In all cases there was an increase in the force, and a prolongation of the period of maintenance, of the maximum movement developed by the stimulated muscles. The method was considered to be sufficiently effective to indicate that programmed stimulation by implanted electrodes would permit functional use of the hand.

Key words: Traumatic paraplegia; Implanted electrostimulation; Electrical stimulation of muscle.

\section{Introduction}

FOR SEVERAL YEARS, the Department of Rehabilitation has conducted studies in the use of implanted stimulators in patients with tetraplegia following spinal cord injury. Implanted stimulators were chosen to avoid the inconvenience and non-specific effects of external stimulation. These ensure a stable position of the electrodes, reduce stimulation parameters and simplify the application of the stimulation system.

In peripheral neurone paralysis muscle stimulation may slow down the process of atrophy of the denervated muscles and may accelerate regeneration of the damaged nerve fibres. We believe that a functionally controlled implanted stimulator might help to maintain the basic functions of the paralysed extremity.

In paralysis of the central neurone, nerve stimulation should produce the desired motor effect and ensure the inflow of stimuli to the spinal cord centres. We also believe that restoring the ability to perform some simple grasping function of the hand in tetraplegic patients would help them to recover some independence and reduce their disability.

\section{Methods}

Before implantation of the first unit a series of studies were conducted to determine the effect of stimulation on the paralysed muscles (Kiwerski, I973). The dessired motor effect was obtained by means of external stimulation of the median nerve. We found that external stimulation of nerves did, in fact, slow down the process of atrophy of the paralysed muscles without producing any harmful effects. The experimental stage included stimulation tests of the urinary bladder in dogs (Dackiewicz et al., I970; Dackiewicz, I97 I; Paśniczek, I974).

The first clinical stimulation test by means of implanted stimulators employed direct muscle stimulation (Borowski et al., I97I). Later, nerve 


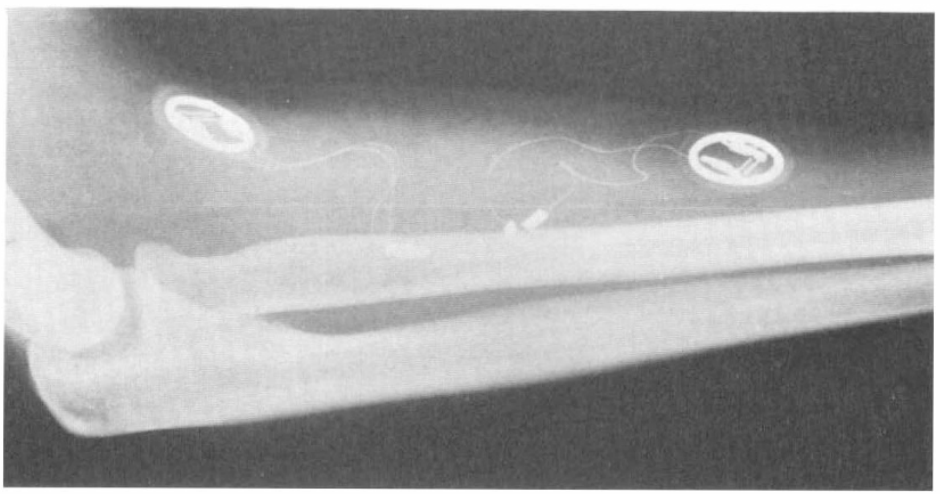

FIG. I

Radiograph showing the stimulators and electrodes.

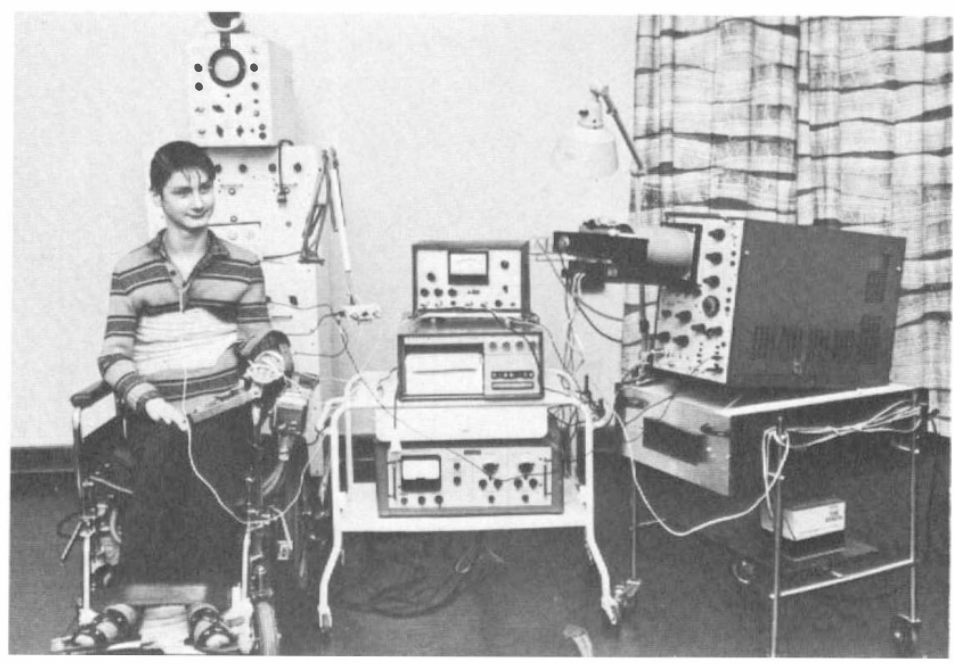

FIG. 2

Examination at tensiometric station.

stimulation was employed and we have subsequently implanted 24 stimulators in 12 patients.

Electrode implantation was done under local anaesthesia as this allows contact with the patient during the procedure, thus permitting better assessment of the effect of the trial stimulation in such a way as to make it most effective without being painful. After exposure of the median nerve at an appropriate level (usually the upper part of the forearm), the electrodes were fixed to the epineurium of the nerve or to the adjacent tissues by means of single thin sutures. After trial stimulation was confirmed, the stimulator was fixed in the subcutaneous tissues beyond the operative section, and the wound was sutured in layers. After the wound healed, localisation of the electrode was checked by a radiogram (Fig. I), and systematic stimulation was started. The stimulation amplitude provided 


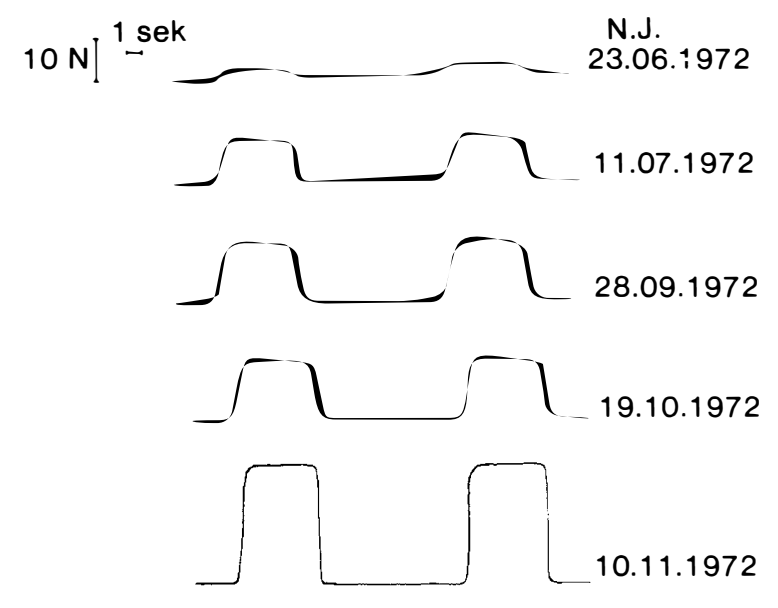

FIG. 3

Increase of force (mechanograms) after electrostimulation.

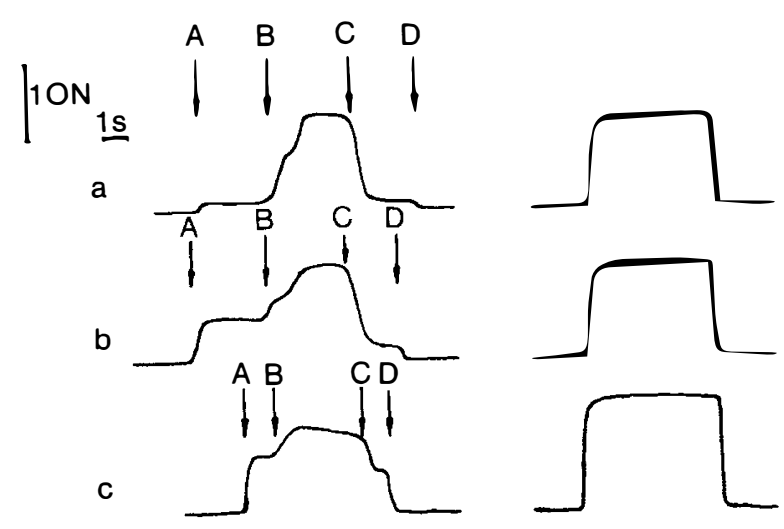

FIG. 4

Support of the stimulation effect (mechanograms) during progress of treatment. Abeginning stimulation; $\mathrm{B}$ - beginning of the patient's active co-operation to enhance the effect of stimulation; C-end of the patient's voluntary activation enhancing the electrical stimulation; D-end of stimulation.

a maximum tetanic contraction of the finger flexors and the opponens pollicis and was switched on by a special programming device for 5 seconds, followed by a 30 second intermission. This cycle, stimulation/rest, was repeated for 5 minutes. After an intermission of 55 minutes the next 5 minute programme was performed. Training lasted for 3-4 hours each day and maximal forces reached by the flexors and opponens pollicis during stimulation were recorded using a specially designed tensiometric apparatus (Fig. 2). The bio-electrical activity of the muscle was recorded during active movement as well as during stimulation; the direct response of the muscle (M reaction) of both upper extremities following external stimulation by a single stimulus of the median nerve was also recorded. The excitability curve $I=f / T$ of nerves of the stimulated and of the contralateral extremity 
TABLE I

\begin{tabular}{rrrrc}
\hline Case & Name & Age/Sex & Level of lesion & $\begin{array}{c}\text { Time injury- } \\
\text { operation } / \text { months }\end{array}$ \\
\hline I & T.P. & $30 \mathrm{M}$ & C6 & $4 \mathrm{~m}$ \\
2 & Z.M. & $40 \mathrm{M}$ & C6 & $3 \mathrm{~m}$ \\
3 & M.J. & $20 \mathrm{M}$ & C7 & 1.5 m \\
4 & Z.T. & $2 \mathrm{I} \mathrm{M}$ & C6 & $2 \mathrm{~m}$ \\
5 & R.K. & $25 \mathrm{M}$ & C6 & $2 \mathrm{~m}$ \\
6 & Z.S. & I8 M & C7 & $2 \mathrm{~m}$ \\
7 & M.R. & $23 \mathrm{M}$ & C6 & $6 \mathrm{~m}$ \\
8 & M.K. & $24 \mathrm{M}$ & C6 & $4 \mathrm{~m}$ \\
9 & E.D. & $29 \mathrm{M}$ & C7 & $3 \mathrm{~m}$ \\
I0 & E.G. & $34 \mathrm{~F}$ & C6 & $6 \mathrm{~m}$ \\
I I & W.K. & I6 M & C6 & $2 \mathrm{~m}$ \\
I 2 & K.S. & $25 \mathrm{M}$ & C6 & $3 \mathrm{~m}$ \\
\hline
\end{tabular}

were noted and the bio-electric activity of flexors and extensors of the extremity (stimulated by means of surface electrodes), was recorded simultaneously with strength measurements. These studies revealed an increase in the force (Fig. 3), and a prolongation of the period of maintenance of the maximal movement developed by the stimulated muscles. The possibility of an active increase by the patient of forces developed by the stimulated (but previously paralysed muscle) was considered, but the effect of active support of stimulation by the patient was more effective the lower the stimulation base. The patient who can independently perform simple movements of his fingers may actively overcome a resistance requiring the use of a force even ten times higher. This effect is illustrated by mechanograms obtained at measurements on the tensiometric apparatus (Fig. 4). Records of bio-electrical activity of finger flexors and opponens correspond to the mechanogram tracings. The support of active contraction by previous stimulation is expressed on the electromyogram by an increased amplitude, synchronisation and a good response of the finger flexors.

\section{Discussion}

The possibility of an active increase by the patient of the force developed by muscles stimulated to contraction by means of implanted stimulators may have practical significance. The functional effect is presumably achieved by the fact that the median nerve orginates from all the brachial plexus roots. In spinal cord damage at $\mathrm{C}^{-}-\mathrm{C}_{7}$ level the spinal centres and the roots from C8-Di may remain undamaged.

Stimulation training may allow connection with the higher levels of the central nervous system via undamaged $\mathrm{C}_{5}$ root fibres. This will be possible after the post-traumatic changes in the spinal cord segment close to the site of injury have resolved. The functional improvement usually appears after a period of application of stimulation as stated by Eccles ( 1962 and 1964), who claims that 'the ease with which the stimuli run along the paths having synaptic connections depends on their utilisation'. In those cases where the physiological connection of muscle with spinal and higher 
centres have a poor efficiency, the stimuli arriving from upper nervous system levels are so weak that they can independently elicit merely trivial active movement.

The development, or clearing of nerve paths by means of stimulation, facilitates movement due to the summation of the physiological and external stimuli which (as a result), may together permit a strong contraction of the previously paralysed muscles. This may in some instances permit a more functional utilisation of a tetraplegic's hand.

In the severely disabled it will presumably be necessary to perform a programmed stimulation of certain muscle groups by means of nerve stimulation if useful function is to be achieved.

\section{RÉSUMÉ}

L'effet de l'électro-stimulation directe sur le nerf médian d'un groupe de patients tétraplégiques est décrit.

Dans tous les cas on a noté une augmentation de la force et une prolongation de la période de maintenance du mouvement maximum développé par les muscles stimulés.

Les résultats de cette méthode ont été considérés comme suffisamment éloquents pour suggérer qu'une stimulation programmée par des électrodes implantés au niveau du membre supérieur permettrait un meilleur usage fonctionnel de la main.

\section{ZUSAMMENFASSUNG}

Es werden die Auswirkungen der kirekten Elektro-stimulation des N. medianus bei Tetraplegikern beschrieben. In allen Fällen kam es zu einer Zunahme der Kraft und einer Verlängerung der Zeit der Beibehaltung des stärksten Bewegungsausmaßes in den stimulierten Muskeln. Das Verfahren scheint geeignet, durch programmierte Muskelstimulationen über implantierte Elektroden die Handfunktion zu verbessern.

\section{REFERENCES}

Borowski, H., WIRski, J. \& PAŚnICZeK, R. (I97I). Zastosowanie stymulatorow implantowanych $\mathrm{w}$ sterowaniu funkcji kończyn u tetraplegików. (Use of implanted stimulators for the control of function of extermities in tetraplegics). Problemy Techniki Medycznej, 3, 267-277.

Dackiewicz, J., Praglowski, J. \& Paśniczek, R. (1970). Wyniki wpasnych prac doświadczalnych nad stymulacją pęcherza moczowego psa. (Results of own experiments on stimulation of the urinary bladder of a dog). Congress of Polish Urologists. Warsaw.

DACKIEWICZ, J. (I97I). Badania porónwnawcze i wyniki wlasnych prac doświadczalnych nad elektrostymulacją pȩcherza moczowego psa. (Comparative studies and results of own experiments on electrostimulation of the urinary bladder ofa dog.) Habilitation thesis, Warsaw.

Eccles, J. C. (1962). Proceedings First Intern. Pharmacology Meeting, 8, I 57.

Eccles, J. C. (1964). The Physiology of Synapses. New York: Academic Press.

KIWERSKI, J. (1973). The effects of electrical stimulation on paralysed muscles in quadriplegics. Polski Tygodnik Lekarski, 28, I 58-159.

PAŚNICZEK, R. (1974). Badanie procesów wymuszania czynności mechanicznych poraźonych narzadów ustroju metodami elektrostymulacji. (Studies on processes of forcing mechanical functions of paralysed body organs by electro-stimulation methods.) Doctoral Thesis. Warsaw Technical University. 